\title{
RIGHT TO JURY TRIAL IN DECLARATORY JUDGMENT ACTIONS: A NARROWING INTERPRETATION*
}

COURTs have long insisted that parties be given the same constitutional right to jury trial in declaratory actions ${ }^{1}$ as they have in non-declaratory proceedings. ${ }^{2}$ To determine whether jury trial should be granted, a simple rule of thumb has been adopted: The right to jury trial is preserved if either party would be entitled to it in any action for which the declaratory action is a substitute. ${ }^{3}$ Proper application of the rule would forestall any argument that

based on a finding of innocence from evidence discovered after conviction, upon motion the judgment of conviction must be set aside, the indictment dismissed, and the defendant returned to his status of innocence. N. X. CODE CRIM. Proc. $\S 697$. This statute was designed to clarify the status of a person pardoned on the ground of innocence. In many states the courts have held that a pardon does not wipe out the pardonee's "conviction", and have failed to distinguish between pardons granted for innocence and those granted for other reasons. See 3 Attorney General's Survey 267-94; Weihofen, The Effect of a Pardon, 88 U. of PA. L. Rev. 177 (1939); Williston, Does a Pardon Blot Out Guilt?, 28 HARv. L. REv. 647 (1915). Despite pardon, a conviction has been used to discredit a witness, disbar an attorney, refuse an application for naturalization, withhold a license to engage in a business, and invoke the provisions of a recidivist statute imposing increased penalties on repeating offenders. See Note, 59 HARv. L. REv. 1174 (1946).

The New York statute differs slightly from the Rhode Island statute involved in the Gametto case. The Garnetto statute orders a court to quash sentence but leaves the judgment of conviction undisturbed, whereas the New York statute orders a court to set aside the judgment of conviction. This difference is of little significance, however, because if a legislature can order a court to quash sentence, there appears to be no reason why it cannot also order a court to set aside the conviction upon which the sentence is based. Legislative power to wipe out the main consequence of conviction-namely, incarceration-should carry with it the power to wipe out the collateral consequences. Thus the New York statute would appear to be constitutional, although this question has not been passed upon by the New York courts.

* United States Fidelity \& Guaranty Co. v. Spring Brook Farm Dairy, Inc., 135 Conn. 294, 64 A.2d 39 (1949).

1. Federal courts and the courts of forty-four states now render deciaratory judgments. Arkansas, Louisiana, Mississippi and Oklahoma courts do not. Developments in the Law-Declaratory Judgments-1941-1949, 62 HARv. L. REv. 787, 791 (1949).

2. See, e.g., Dickinson v. General Accident, Fire \& Life Assur. Corp., 147 F.2d 396 (9th Cir. 1945); Pacific Indemnity Co. v. McDonald, 107 F.2d 446 (9th Cir. 1939).

Writers on the subject unanimously agree that parties' rights to jury trial are governed by the same rules which apply in non-declaratory actions. ANoErson, Actions ron DeClaratory JudGMENTS 498-9 (1940); BorCHARd, DECLARATORY JudGMENTS 401 (2d ed. 1941) ; Hearings Before Senate Subcommittee on Judiciary on H.R. 5623, 70th Cong., 1st Sess. (1928) passin; Morrison, Azailability of the Federal Declaratory Judgment Act for Life Insurance Cases, 23 A.B.A.J. 788, 789 (1937). This view is reflected in the adoption of the new Judicial Code, which omits any reference to jury trial in declaratory actions. 28 U.S.C. $\$ \S 2201-2$ (1948). The Federal Rules of Civil Procedure govern here as in other actions. Vanneman \& Kutner, Declaratory Judgments in the Federal Courts, 9 OتIо ST. L. J. 209, 220 (1948); Revisers' Notes to 28 U.S.C. $\$ 2202$ (Cong. Serv. 1948).

3. E.g., Pacific Indemnity Co. v. McDonald, supra note 2.

In a situation analogous to the principal case a federal court has held that where the 
declaratory judgments are unconstitutional as a deprivation of the right to jury trial. ${ }^{4}$ Occasional decisions ${ }^{5}$ within the past several years, however, have shown either a lingering misunderstanding of the nature of declaratory judgments or an inadequate and unrealistic application of the rule of thumb.

United States Fidelity \& Guaranty Co. v. Spring Brook Farn Dairy, Inc., a recent Connecticut case, illustrates the apparently faulty reasoning by which full protection of jury-trial rights can be denied. $i$ Here the plaintiff had issued two insurance policies to the dairy. One covered all its liability under the Connecticut Workmen's Compensation Act; ${ }^{8}$ the other covered ordinary motor

declaratory defendants could have sued at law or equity, their right to choose cither form of action should be recognized in the declaratory action and jury trial should be granted on the issues triable in the law action. Ryan Dist. Corp. v. Caley, 51 F.Supp. 377 (E.D. $\mathrm{P}_{2}$. 1943) (motion to strike demand for jury-denied), aff'd on other grounds, 147 F.2d 138 (3rd Cir. 1945) (appeal from judgment n.o.v.-earlier issue not raised), ccrl. denied, 325 U.S. 859 (1945). See also Linahan v. Linahan, 131 Conn. 307,39 A.2d 895 (1944) (seeking a declaration of rights and duties under a trust). Sec, c.g., (Ameriean) Lumbermens Mut. Cas. Co. v. Timms \& Howard, 108 F.2d 497, 499 (2d Cir. 1939) (seeking declaration that truck was being used in manner not covered by policy); Lippman $v$. Shapiro, 151 Fla. 327, 329, 9 So.2d 636 (1942) (dismissal from equity of declaratory petition seeking adjudication of plaintiff's rights under alleged assignment of open accounts in order to preserve defendant's jury rights at lav). Borchard approves this rule. BORCHARD, op. cit. supra note 2 , at 400-1.

This rule perhaps requires modification to include the few situations where a declaratory plaintiff could also have brought an action seeking equitable relief, as in suits for cancellation of insurance policies. If it treats the declaratory action as obverse to the equity suit, the court may here refuse jury trial. Id. at 400 n.63.

4. See, e.g., Petition of Kariher, 284 Pa. 455, 469-70, 131 Atl. 265, 270 (1925) (Uniform Declaratory Judgments Act); Milles v. Strong, 68 Conn. 273, 286-7, 36 At1. 55, 58-9 (1896) (upholding Connecticut act's constitutionality though jury trial not specifically mentioned). See also cases cited note 2 supro.

The jury trial provision in the Uniform Declaratory Judgments Act, providing that issues of fact in declaratory actions should be tried and determined as issues of fact in other civil actions are tried and determined, was inserted ". . to avoid either constitutional or statutory objections to the act." Report of the Commiltec on Declaralory Judgmeits, Handroor of tHe Nat. CoNf. of Concar'rs. on Untromar State Laws 173, 180 (1920). On the federal act see 3 Mioore, Federal Practice 3231-2 (1938). One writer has mistakenly argued that jury trial should not be required in any declaratory actions. Willis, Constitutional Law 555 (1936).

5. See cases cited in Developncuts in the Law-Declaralory Judgments-19\$1-1949, 62 HARv. L. Rev. 787, 816, nn. 218-21 (1949).

6. 135 Conn. 294, 64 A.2d 39 (1949).

7. The applicable portion of the Connecticut constitution resds, "The right of trial by jury shall remain inviolate" Cons. CoNsr. Art. I, \$21. This section, a minimum guarantee, has been made more explicit by statute Cosv. REv. STAT. \$7936 (1949), discussed in Clark, Code Pleading 97 (2d ed. 1947). These principles, as regards declaratory judgments, are embodied in CoNN. Prac. BK. $\$ 251(f)$ (1948), which, as interpreted in the principal case, provides that issues of fact necessary to the determination of the cause should be submitted to the jury as in other actions. United States Fidelity \& Guaranty Co. v. Spring Brook Farm Dairy, Inc, 135 Conn. 294, 297-S, 64 A.2d 39, 41 (1949).

8. ConN. Rev. Stat. $\S 8416-94$ (1949). 
vehicle liability. Anticipating a tort suit against the dairy for the negligence of its driver in causing the death of the deceased, the insurer sought a declaration that deceased was an employee within the meaning of the Compensation Act. If such were the case, the Act's exclusive remedy provision ${ }^{0}$ would have preciuded liability in tort. The deceased's administrator claimed the case for the jury list. On appeal, the Supreme Court of Errors held that the trial court had erred in denying plaintiff's motion to have the case tried without jury. ${ }^{10}$

The court used an historical test ${ }^{11}$ in reaching its conclusion. Since workmen's compensation was unknown when the Connecticut constitution was adopted, ${ }^{12}$ the issue of a workman's coverage by the Act could not have been tried to a jury at that time. Nor had the legislature extended the right of jury trial to issues arising under the statute. ${ }^{13}$

If only compensation issues were raised, as the court assumed, the declaratory action might justifiably have been treated as obverse to a proceeding under the Act, and hence triable without a jury. But on the facts of the case this assumption was not justified. Had the declaratory action not taken the initiative from the administrator, he would have had the alternative of sting in tort. In the tort action, the insured would have pleaded by way of defense that deceased was an employee as defined by the Act and the administrator was therefore precluded from suing at law. ${ }^{14}$ In this action the administrator

9. Conn. Rev. Stat. § 7419 (1949).

10. The judgment of the Supreme Court of Errors was as favorable to the administrator, however, as was the judgment entered below. The court found that as a matter of law deceased was not an employee within the meaning of the Workmen's Compensation Act, Conn. Rev. STAT., \$\$7416-94 (1949).

Although the question of jury trial was argued in the briefs of counsel on each side, the line of argument here presented was not clearly suggested to the court. Sce Brief for Appellee, pp. 2-5, United States Fidelity \& Guaranty Co. v. Spring Brook Farm Dairy, Inc., 135 Conn. 294, 302-303, 64 A.2d 39, 43 (1949).

11. Courts generally grant jury trial in accordance with the so-called historical test, i.e., if the code action is one which would have been tried at law before the codes, a right to jury trial exists. CLARK, op. cit. supra note 7, at 91-102; James, Trial By Jury and the New Federal Rules, 45 Y ALE L.J. 1022, 1023 (1936).

12. The Connecticut constitution was adopted in 1818; the Connecticut workmen's compensation law was first enacted in 1913.

13. The Connecticut Workmen's Compensation Act provides that acceptance by employer and employee of the act shall be deemed to include a mutual waiver of the right to jury trial on "... all questions affecting compensation...." Conn. Rev. Stat. $\$ 7419$ (1949).

Most state workmen's compensation acts have similar provisions. The court in the principal case, perhaps influenced by this provision, wavered between the tradition which denies that workmen's compensation acts unconstitutionally limit the right to jury trial, e.g., State of Washington ex rel. Davis-Smith Co. v. Clausen, 65 Wash. 156, 117 Pac. 1101 (1911) (alternate holding), and the practice which grants full jury trial rights in declaratory actions, note 2 supra.

14. Hammett v. Vogue, Inc., 179 Tenn. 284, 165 S.W.2d 577 (1942). Contra: Ziegler v. Maurer, 15 N.J.Misc. 654, 194 Atl. 612 (Sup.Ct. 1937) (by implication). See sources cited in 1 Schnerder, Workmen's Compensation 243 (3d ed. 1941). The effect 
would have been entitled to jury trial. ${ }^{15}$ By denying in a declaratory action the jury trial which the administrator would have had in the tort action, the court deprived him of a right possessed before passage of the declaratory judgment statute ${ }^{16}$

Unless courts consider all possible actions which parties might bring, the declaratory judgment procedure will become an important device for rewarding the fast-moving insurer. Most of the actions in which jury trial is made an issue are petitions by insurance companies for declarations of non-liability because of alleged non-coverage of policies. ${ }^{17}$ The denial of a jury trial in these actions can have an important bearing on the outcome, for juries are prone to settle any doubts regarding an insurer's liability in favor of the injured party. ${ }^{18}$

of workmen's compensation statutes on common law actions is discussed also in HoroVITZ, WORKMEN'S COMPENSATION 316-53 (1944).

15. Conn. Rev. Stat. $\$ 7936$ (1949). Where the issue of coverage is a mixed question of fact and law, it goes to the jury. Umsted v. Scofield Engineering Const. Co., 203 Cal. 224, $263 \mathrm{Pac}$. 799 (1928) (error for trial court to find as matter of law that deceased was special employee of defendant).

Since under one of the administrator's theories of recovery questions of fact did exist in the Brook Farm case, the issue of coverage by the Compensation Act should have been for the jury. The lower court did permit a jury trial and judgment was entered for defendant on the basis of interrogatories and special findings by the court. Transcript of Record, pp. 12-18, United States Fidelity \& Guaranty Co. v. Spring Brook Farm Dairy, Inc., 135 Conn. 294, 64 A.2d 39 (1949).

16. This conclusion is not open to the unqualified objection that the employer could have petitioned for a compensation hearing and thus, by acting before the administrator had sued at law, have secured a determination of issues by compensation officials. Some acts do not provide for employer-initiated hearings. E.g., Pennsylvania, PA. Star. Axzi, tit. 77, §751 (Supp. 1948); and New Jersey, N.J. Star. Aws. \$34:15-50, 51 (1940).

If the law provides that employers may secure hearings, one of three courses will be followed. In California, all issues raised in the hearing will be decided regardless of possible effect on law actions either already in the courts or under preparation. Communication to the YaLE Law Journal from Dan MLurphy, Jr., Chairman, Californiz Industrial Accident Commission, September 16, 1949. An opposite result may be reached in Indiana and New York, where compensation officials wait for the termination of law actions even though the employer may have sought a compensation hearing before the law action was filed. Communications to the YaIE Law Joursul from Maurice $T$. Harrell, Chairman, Industrial Board of Indiana, September 19, 1949, and Henry J. Clay; General Counsel, New York Workmen's Compensation Board, September 19, 1949. One Connecticut commissioner takes a mid-way position and determines his course of action according to the facts in each case. Communication to the YALE LAw Joursal from Louis Sachs, Commissioner, Third Congressional District, Connecticut, September 22, 1949.

17. BORCHARD, op. cit. stpra note 2, at 402. At one time jury trial was demanded only occasionally in declaratory actions. Id. at 403. It is apparently being demanded with increasing frequency today. Devclopments in the Lau-Declaratory Judgmenis1941-1949, 62 HARV. L. REv. 787, 836 (1949).

18. That parties regard jury trial as being important in negligence actions has long been recognized. Clark \& Shularan, A Study of Law Adsrnistrationi is Cosirecticur 60 (1937). Jury trial is significant not only in that there is greater likelihood of a plaintiff's verdict, but also in that the chance of a plaintiff's "getting to the jury" is a 
The declaratory action already possesses certain procedural advantages for insurers. It gives them a choice of forum ${ }^{19}$ which formerly lay only with the insured or the injured party in a tort action or an action on the policy. ${ }^{20}$ And in contrast to the general verdict commonly rendered by a jury in an action on a policy, ${ }^{21}$ the declaratory action usually involves only a special verdict, where jury sympathies are thought to operate less freely. ${ }^{22}$

The existing benefits to insurers are perhaps inherent in a declaratory judgment proceeding. The further advantage bestowed in the Brook Farm case is not; nor is it an advantage which the framers of the statute intended to grant. $^{23}$

significant factor in insurance company settlement policies. James, Accident Liability Reconsidered: The Impact of Liability Insurance, 57 Yale L.J. 549, 567-8 (1948).

One study revealed that ". . . two-thirds of the motor vehicle cases tried by a jury are terminated in favor of the plaintiff." REPORT bY THE CONMIITIE to Study CoNpensation for Automobile Accidents to the Columbia University Council for ReSEARCE IN THE SOCTAL Sctences 90 (1932). More recent studies indicate an even greater percentage of plaintiff verdicts. James, Functions of Judge and Jury in Negligence Cases, 58 Y ALE I.J. 667, 687 (1949).

In addition, if judgment in the declaratory action is adverse to the defendant, he can no longer reach the tort-feasor's insurance. While the declaratory defendant may still have a cause of action against the tort-feasor, as far as the defendant is concerned the tort-feasor is now uninsured. Recovery under these conditions may be difficult. For example, the Columbia study reported 2,500 cases of temporary disability where there was insurance and 900 where there was not. Claimants received payment in 86 per cent of the insurance cases while payment was received in only 27 per cent of the uninsured cases. Columbia UnIVERSITY REPORT, stipra, at 203, 204.

19. For discussion of this and possible other procedural advantages see Devclopments in the Law-Declaratory Judgments-1941-1949, 62 HARv. L. REv. 787, 836-8 (1949).

20. Under modern standard policy provisions the injured party is given a direct right of action against insurer, once insurer liability has been established by judgment or agreement of all parties. James, Accident Liability Reconsidercd: The Impact of Liability Insurance, 57 YALE L.J. 549, 563 (1948).

21. BORCEARD, op. cit. supra note 2, at 674-5.

22. Ibid.; Cull, Practical Use of Federal Declaratory Judgment Act in Liability It1surance Cases, 8 J. Bar Ass'N. of THE State of Kansas, 195, 206-8 (1939) ; James, Finctions of Judge and Jury in Negligence Cases, 58 Yale L. J. 667, 683-4 (1949).

23. The courts as well as the draftsmen of the Uniform Declaratory Judgments Act, 9 U.L.A. 215-60 (1942) and the Federal Declaratory Judgments Act, 28 U.S.C. $\$ \$ 2201-2$ (1948) have emphasized that the declaratory action was not designed to afford either party a procedural advantage. See note 2 supra. The purposes of declaratory judgments are listed by Borchard, The Uniform Declaratory Judgments Act, 18 MiNN. L. REv. 239, 257-61 (1934). See also Sunderland, A Modern Evolution in Remedial Rights-The Declaratory Judgment, 16 MrсH. L. Rev. 69 (1917). 